\title{
Sustainable Use of Chemical in Agricultural Soils and Implications for Precision Agriculture
}

\author{
Olusola T. Kayode ${ }^{1 *}$, Ahzegbobor P. Aizebeokhai ${ }^{1}$, Abiodun M. Odukoya ${ }^{2}$, \\ Hilary I. Okagbue ${ }^{3}$ \\ ${ }^{1}$ Department of Physics, Geophysics Group, Covenant University, Ota, Nigeria \\ ${ }^{2}$ Department of Geosciences, Faculty of Science, University of Lagos, Akoka, Nigeria \\ ${ }^{3}$ Department of Mathematics, Covenant University, Ota, Nigeria
}

Received: 03/8/2020 Accepted: 14/10/2020 Published: 20/06/2021

\begin{abstract}
This study characterized and assessed the geostatistical variations of some essential macronutrients ( $\mathrm{Ca}, \mathrm{P}, \mathrm{Fe}, \mathrm{Na}, \mathrm{K}, \mathrm{Al}, \mathrm{Mg}$ and $\mathrm{Ti})$ for further environmental monitoring, planning and remediation using geochemical analysis in two commercial farms. Twenty soil samples were collected at the depth of $50 \mathrm{~cm}$ to $70 \mathrm{~cm}$ below the subsurface from the study areas that is, Landmark university farm representing the northcentral and Covenant university farm representing southwest Nigeria, respectively. Inductively coupled plasma and mass spectrometry (ICPMS) was used to analyze the samples at the Acme laboratory, Canada. The statistical results indicate that the following pair of elements \{Ca-Mg, P-Mg, Fe-P, Fe-Al, Ca-K, Mg-K, and Na-K\} are significantly positively correlated at 0.05 significance in the areas. The mean and median test revealed that iron (Fe) and titanium (Ti) content are the same in both study areas. The findings among others imply that deficient essential nutrients can be applied as chemical fertilizers to farmland and thereby enhancing sustainable agricultural production.
\end{abstract}

Keywords: Geochemical analysis, geostatistics, macronutrients, precision agriculture, soil, sustainable agriculture

\section{Introduction}

Soil is a vital resource required for plant growth. The ability of a soil to supply elements necessary for plant growth is termed soil fertility. Soil degradation is a decline in soil quality and a consequence of intensive land use management (1). So, macro and micronutrients are the nutrients needed for the utmost plant growth but macronutrients are needed in larger quantities for basic plant growth and development (2-4). Essential macronutrients necessary for good soil functioning are further divided into primary macronutrients which include nitrogen $(\mathrm{N})$, phosphorus $(\mathrm{P})$ and potassium $(\mathrm{K})$, and secondary macronutrients, magnesium $(\mathrm{Mg})$, calcium $(\mathrm{Ca})$ and sulphur $(\mathrm{S})$. Aluminium $(\mathrm{Al})$, iron $(\mathrm{Fe})$ and thallium (Ti) are major elements in rocks although they appear as trace elements in water due to their slow mobility on the earth's surface (5). Micronutrients, also known as trace elements are needed in micro quantities and typically have a higher concentration in surface soil and decrease with soil depth (6). An increase in soil $\mathrm{pH}$ reduces the availability of micronutrients in soil except for molybdenum whose availability increases with increasing $\mathrm{pH}$ (6).

Plants take in other trace elements in varying degrees but may not be considered essential mineral elements. Therefore, soil fertility and plant nutrition should be studied simultaneously, as both essential and nonessential elements can be toxic to soil and plants if accumulated at a very high concentration (7-8). There is nutrient deficiency whenever essential nutrients are not available to meet the need of a growing plant. Also, toxicity occurs when there is an excess of nutrients for plants' normal growth (9). Soil testing, plant analysis or visual field observations are the basic tools for identifying this deficiency or toxicity of nutrients in soils (9).

Because soil nutrients availability is highly variable in space and time (10-11), only a portion of the plant's root may have access to nutrient-rich patches. However, high nutrient availability in soil enables greater capacity for photosynthesis, increased carbon import, more root growth and higher nutrient uptake (12). The studies of soil nutrient variations, dispersion, mobility, heterogeneity, interaction with organisms and enzymatic activities have enhanced the practice of precision farming in several nations of the world such as Turkey, China, Brazil, India and the United States of America (9) (13-27), but limited researches exist in the tropics on the importance of soil nutrients. Most commercial farms in Nigeria have adopted the use of chemical fertilizers and animal manure to increase soil fertility without first-hand information on the nutrient status of the farms. When the nitrogen and phosphorus supplied by these chemical fertilizers are not fully utilized by the growing plants, they are lost from the farmlands and then negatively impact air and groundwater quality (28).

Precision agriculture is a site-specific management system

*Correponding author: Olusola T. Kayode, Department of Physics, Geophysics Group, Covenant University, Ota, Nigeria. E-mail: olusola.kayode@covenantuniversity.edu.ng 
that adopts information and technology of sources of data from the soil, nutrients, moisture, and crops. This information is used in farm management for optimum profitability, long-term sustainability of agricultural production and the protection of the environment (29-33). When precision farming is practiced, inputs such as fertilizers will only be applied where it is needed and when it is needed (34).

The study aims to quantify the essential macronutrients in the soils within the study area and geo-statistically compare the variability of these nutrients. The result of the study serves as quick reference material for farmers and agricultural decisionmakers in the selected locations in southern and northcentral states of Nigeria.

\section{Materials and Methods}

Soil is a vital resource required for plant growth. The ability of a soil to supply elements necessary for plant growth is termed soil fertility. Soil degradation is a decline in soil quality and a loss of soil fertility.

\subsection{Site Description}

The main study areas are the two commercial farms of Landmark, University Omu-Aran (L1) and Covenant University Ota (L2). Omu-Aran falls within the north-central part of Nigeria bounded by Longitudes $40^{\circ} 59^{\prime} 47.26^{\prime \prime} \mathrm{E}$ and $50^{\circ} 29^{\prime} 41.667^{\prime \prime} \mathrm{E}$, and Latitudes $80^{\circ} 0$ ' $14.8392^{\prime \prime} \mathrm{N}$ and $80^{\circ} 30^{\prime} 15.5664^{\prime} \mathrm{N}$ (Figure 1). On the other hand, Covenant University Ota is located in southwest Nigeria bounded by Latitude $6^{\circ} 40^{\prime} 41.0988^{\prime \prime} \mathrm{N}$ and Longitude $3^{\circ}$ 9' 49.6908"E.

Omu-Aran (L1) falls within the schist belt of the Basement complex while Ota CU farm (L2) falls within the sedimentary Basins of Nigeria (35-36). Omu-Aran experiences an average annual temperature of $24.9^{\circ} \mathrm{C}$ and about $1273 \mathrm{~mm}$ of precipitation annually. Ota in Ogun State has an average annual temperature of $26.5^{\circ} \mathrm{C}$ and an annual average rainfall of $1057.9 \mathrm{~mm}(37)$. Topography is one of the striking characteristics of Omu-Aran farm with an elevation range from $550 \mathrm{~m}$ to $575 \mathrm{~m}$ above the sea level. Ota (L2) has an elevation range from $49 \mathrm{~m}$ to $52 \mathrm{~m}$ above the sea level. Omu-Aran is well known for mining activities and farming but Ota is predominantly known for small scale farming and industrialization.

The two locations are commercial farms used for growing several crops such as vegetables, rice, palm trees and maize. There are continuous tillage and fertilizer application on the farmland in other to meet the demand and supply chain. To prevent soil degradation, the natural nutrient content of the farm soils should be investigated and necessary recommendations on the use of fertilizers are proffered on the soil.

\subsection{Soil sampling and field work}

Soil samples were collected along 20 traverses on the two selected farmlands between July and December 2018. The farms are commercial farms being managed by the two universities farm managers. The soil samples were picked just before the planting season at an undisturbed depth of $50 \mathrm{~cm}$ to $70 \mathrm{~cm}$ below the subsurface. In Landmark farm, 8 soil samples labelled soil 1 to soil 8 were collected along the traverses and 12 samples (soil 9 20) were collected from Covenant farm. Soil samples were bulked to obtain a composite sample of about $5 \mathrm{~kg}$ of fresh soils. Geographical coordinates were recorded at each sampling point using Garmin Etrex 20, GPS unit. Soil samples were taken to Bureau Veritas of Acme Laboratory Canada.

\subsection{Laboratory analysis of the samples}

Soil samples collected were sealed, packaged and sent for analysis at Acme laboratories limited, bureau veritas Vancouver, Canada in December 2018. Eight essential elements necessary in good soils are mentioned in this paper. The eight macro elements are calcium $(\mathrm{Ca})$, phosphorus $(\mathrm{P})$, magnesium $(\mathrm{Mg})$, titanium $(\mathrm{Ti})$, aluminium $(\mathrm{Al})$, sodium $(\mathrm{Na})$, iron $(\mathrm{Fe})$ and potassium $(\mathrm{K})$. The prepared sample is digested to complete drying with an acid solution of (2:2:1:1) $\mathrm{H}_{2} \mathrm{O}$-HF- $\mathrm{HCIO}_{4}-\mathrm{HNO}_{3}$ - $\mathrm{HCL}$ was added to the residue and heated using a mixing hot block. After cooling, the solutions are transferred to test -tubes and brought to volume using dilute HCL. A $0.25 \mathrm{~g}$ split of sample is analyzed using the inductively coupled plasma mass spectrometry (ICP-MS). The detection limit was $0.01 \%$ for $\mathrm{Ca}, \mathrm{Mg}, \mathrm{Al}, \mathrm{Fe}$ and $\mathrm{K}$ and $0.001 \%$ for $\mathrm{P}, \mathrm{Ti}$ and $\mathrm{Na}$. The percentage composition in the samples was indicated in the result.

\subsection{Statistical Analysis}

The obtained data were analysed with statistical package for social sciences (SPSS) version 23. Averages of each variable as described by the data in the results were used for the analysis. The essential macronutrient data of the analysis from the two locations (L1 and L2) were subjected to descriptive statistics and correlation matrix at the 0.05 significance levels.

\section{Results and Discussion}

The results from the ICPMS analysis of the nutrients uptake in the soil samples are presented in Tables 1 to 9 .

Sustainable precision agriculture practices require adequate knowledge of soil fertility. The condition of the soil at the beginning of the planting season is paramount to the type of crops and the amount of fertilizers to be added to the soil. This information will aid in the proper application of fertilizers that is, the type, quantity, and rate to be added. The soil analysis result indicates that the nutrients distribution in locations 1 and 2 are almost evenly distributed across the profiles except for aluminium $(\mathrm{Al})$, iron $(\mathrm{Fe})$ and potassium $(\mathrm{K})$ that varies along the traverses (Table 1). For location 1, the median content of titanium is more than the mean value (Table 2). Geostatistical result for location 1 (Omu-Aran) suggests that the following nutrients are highly positively correlated at 0.05 level of significance $\mathrm{P}-\mathrm{Ca}$, $\mathrm{Mg}-\mathrm{Ca}, \mathrm{P}-\mathrm{Mg}$, Al-Ca, Al-Mg, Al-P, Ca-Na, P-Na, Mg-Na, Fe-P, $\mathrm{Fe}-\mathrm{Al}, \mathrm{K}-\mathrm{Ca}, \mathrm{K}-\mathrm{Ca}, \mathrm{K}-\mathrm{Mg}$, K-Al, K-Na (Tables 3 and 4). This result indicates that an increase in one of the nutrients automatically leads to an increase in the other and vice versa across the farmlands.

For Location 2, all the nutrients analyzed were somewhat evenly distributed across the traverses except for aluminum and iron $(\mathrm{Fe})$ (Table 5). The median content of aluminum is more than the mean value in location 2 (Table 6). Elsewhere, the mean is greater than the median. Also, Tables 7 and 8 revealed that these paired nutrients are positively correlated that is, $\mathrm{Ca}-\mathrm{Mg}, \mathrm{P}-\mathrm{Mg}$, Ti-Ca, Ti-P, Ti-Mg, Fe-P, Fe-Al, Ca-K, Mg-K and Na-K across Location 2. This suggests that whenever there is an increase in the accumulation of one there will be in the other and vice versa. 


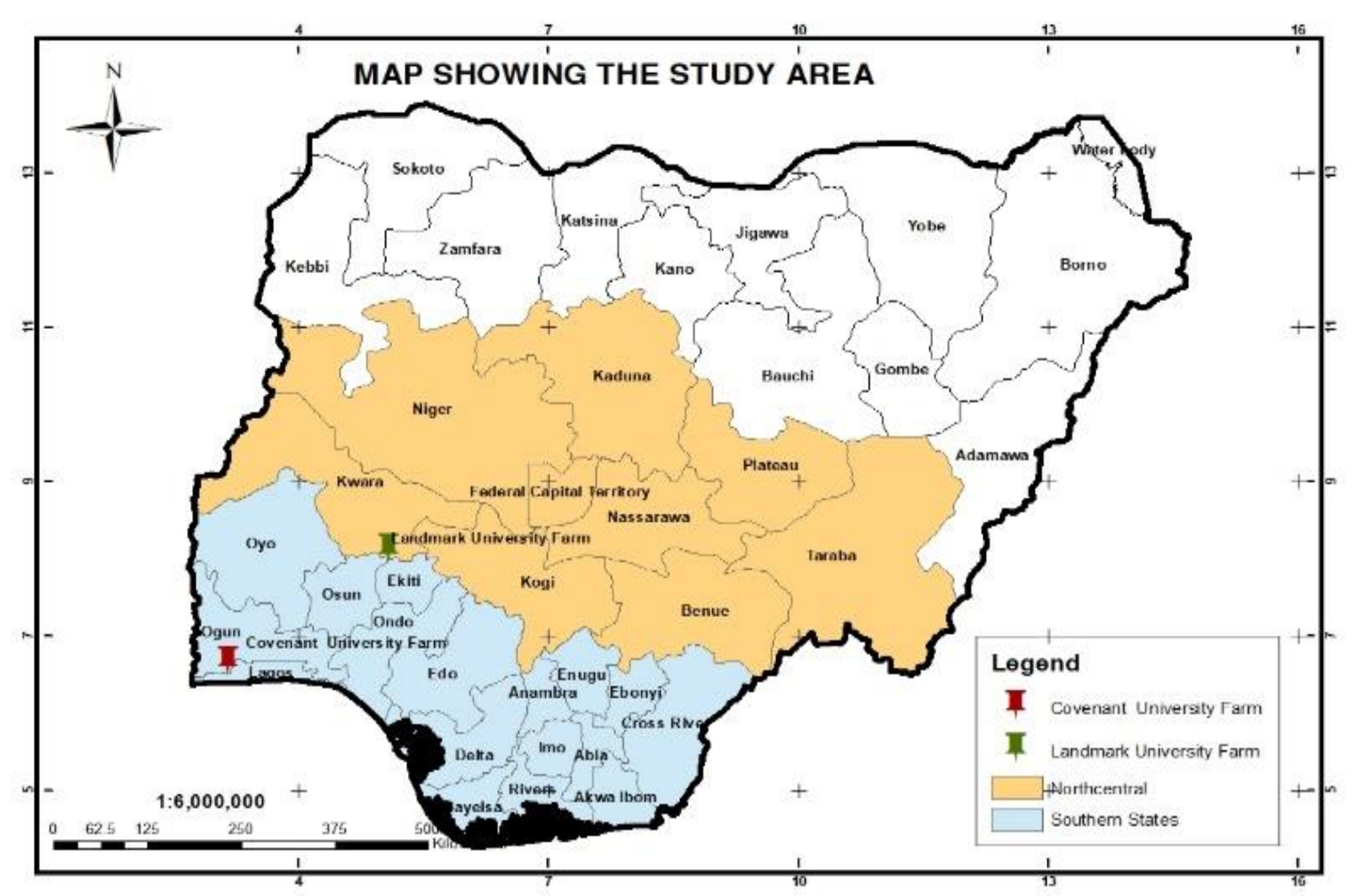

Figure 1: Map of Nigeria showing the study area.

Table 1: Results for macronutrients analyzed from soil samples from Landmark farm (Acme Lab. Canada).

\begin{tabular}{lcccccccc}
\hline Analytes (\%) & $\mathrm{Ca}$ & $\mathrm{P}$ & $\mathrm{Mg}$ & $\mathrm{Ti}$ & $\mathrm{Al}$ & $\mathrm{Na}$ & $\mathrm{Fe}$ & $\mathrm{K}$ \\
\hline MDL & 0.01 & 0.001 & 0.01 & 0.001 & 0.01 & 0.001 & 0.01 & 0.01 \\
Soil 1 & 0.06 & 0.024 & 0.07 & 0.548 & 5.47 & 0.012 & 2.75 & 0.04 \\
Soil 2 & 0.05 & 0.019 & 0.06 & 0.480 & 4.46 & 0.007 & 2.29 & 0.03 \\
Soil 3 & 0.04 & 0.023 & 0.06 & 0.620 & 5.61 & 0.008 & 2.81 & 0.04 \\
Soil 4 & 0.05 & 0.022 & 0.07 & 0.603 & 6.50 & 0.007 & 2.98 & 0.04 \\
Soil 5 & 0.07 & 0.021 & 0.07 & 0.583 & 5.78 & 0.008 & 2.75 & 0.04 \\
Soil 6 & 0.04 & 0.026 & 0.07 & 0.591 & 6.99 & 0.008 & 3.24 & 0.04 \\
Soil 7 & 0.44 & 0.069 & 0.25 & 0.599 & 9.33 & 0.493 & 4.19 & 2.46 \\
Soil 8 & 0.52 & 0.049 & 0.20 & 0.408 & 7.29 & 0.767 & 2.66 & 2.90 \\
\hline
\end{tabular}

MDL - measurement detection limit

Table 2: Descriptive statistics for the analysed soil samples from Landmark farm

\begin{tabular}{lcccccccc}
\hline Statistic & $\mathrm{Ca}$ & $\mathrm{P}$ & $\mathrm{Mg}$ & $\mathrm{Ti}$ & $\mathrm{Al}$ & $\mathrm{Na}$ & $\mathrm{Fe}$ & $\mathrm{K}$ \\
\hline Arithmetic mean & 0.1588 & 0.0316 & 0.1063 & 0.5540 & 6.4288 & 0.1638 & 2.9588 & 0.6988 \\
Geometric mean & 0.0887 & 0.0284 & 0.0900 & 0.5492 & 6.2882 & 0.0241 & 2.9166 & 0.1103 \\
Harmonic mean & 0.0639 & 0.0263 & 0.0804 & 0.544 & 6.1559 & 0.0107 & 2.8791 & 0.0503 \\
Quadratic mean & 0.2451 & 0.0358 & 0.1271 & 0.5582 & 6.5764 & 0.3224 & 3.0057 & 1.3449 \\
Median & 0.055 & 0.0235 & 0.0700 & 0.5870 & 6.1400 & 0.0080 & 2.7800 & 0.0400 \\
SD & 0.1997 & 0.0178 & 0.0746 & 0.0735 & 1.4816 & 0.2970 & 0.5658 & 1.2285 \\
Skewness & 1.4790 & 1.7470 & 1.5610 & -1.4130 & 0.9310 & 1.6930 & 1.6210 & 1.4790 \\
\hline
\end{tabular}


Table 3: Correlation matrix for the pair of nutrients in soil samples for Landmark farm

\begin{tabular}{|c|c|c|c|c|c|c|c|}
\hline $\mathrm{R}$ & $\mathrm{P}$ & $\mathrm{Mg}$ & $\mathrm{Ti}$ & $\mathrm{Al}$ & $\mathrm{Na}$ & $\mathrm{Fe}$ & $\mathrm{K}$ \\
\hline $\mathrm{Ca}$ & 0.906 & 0.957 & -0.502 & 0.732 & 0.989 & 0.42 & 0.999 \\
\hline $\mathrm{P}$ & & 0.987 & -0.156 & 0.895 & 0.844 & 0.744 & 0.914 \\
\hline $\mathrm{Mg}$ & & & -0.281 & 0.855 & 0.908 & 0.646 & 0.961 \\
\hline $\mathrm{Ti}$ & & & & 0.141 & -0.582 & 0.499 & -0.487 \\
\hline $\mathrm{Al}$ & & & & & 0.669 & 0.894 & 0.746 \\
\hline $\mathrm{Na}$ & & & & & & 0.315 & 0.988 \\
\hline $\mathrm{Fe}$ & & & & & & & 0.438 \\
\hline
\end{tabular}

Table 4: Significance table for the correlation matrix for Landmark farm (L1)

\begin{tabular}{|c|c|c|c|c|c|c|c|}
\hline $\mathrm{p}$ value & $\mathrm{P}$ & $\mathrm{Mg}$ & $\mathrm{Ti}$ & $\mathrm{Al}$ & $\mathrm{Na}$ & $\mathrm{Fe}$ & $\mathrm{K}$ \\
\hline $\mathrm{Ca}$ & 0.002 & 0.000 & 0.205 & 0.039 & 0.000 & 0.300 & 0.000 \\
\hline $\mathrm{P}$ & & 0.000 & 0.712 & 0.003 & 0.008 & 0.034 & 0.001 \\
\hline $\mathrm{Mg}$ & & & 0.500 & 0.007 & 0.002 & 0.084 & 0.000 \\
\hline $\mathrm{Ti}$ & & & & 0.739 & 0.130 & 0.208 & 0.221 \\
\hline $\mathrm{Al}$ & & & & & 0.070 & 0.003 & 0.034 \\
\hline $\mathrm{Na}$ & & & & & & 0.448 & 0.000 \\
\hline $\mathrm{Fe}$ & & & & & & & 0.278 \\
\hline
\end{tabular}

Table 5: Result for soil analysis for Covenant farm (L2) from Acme Laboratory, Canada

\begin{tabular}{lcccccccc}
\hline Analytes (\%) & $\mathrm{Ca}$ & $\mathrm{P}$ & $\mathrm{Mg}$ & $\mathrm{Ti}$ & $\mathrm{Al}$ & $\mathrm{Na}$ & $\mathrm{Fe}$ \\
\hline Soil 9 & 0.06 & 0.049 & 0.07 & 0.346 & 7.63 & 0.013 & 10.13 \\
Soil 10 & 0.01 & 0.039 & 0.05 & 0.323 & 8.29 & 0.009 & 13.64 \\
Soil 11 & 0.02 & 0.046 & 0.05 & 0.348 & 8.01 & 0.008 & 13.8 \\
Soil 12 & 0.05 & 0.031 & 0.07 & 0.375 & 8.32 & 0.010 & 7.20 & 0.23 \\
Soil 13 & 0.02 & 0.039 & 0.06 & 0.349 & 8.56 & 0.009 & 9.15 & 0.19 \\
Soil 14 & 0.02 & 0.033 & 0.06 & 0.370 & 8.17 & 0.008 & 7.45 & 0.23 \\
Soil 15 & 0.07 & 0.016 & 0.06 & 0.269 & 3.32 & 0.714 & 2.42 \\
Soil 16 & 0.08 & 0.031 & 0.15 & 0.586 & 4.17 & 0.525 & 3.72 \\
Soil 17 & 0.18 & 0.072 & 0.39 & 0.993 & 7.59 & 0.208 & 11.71 \\
Soil 18 & 0.18 & 0.052 & 0.25 & 0.49 & 6.56 & 0.200 & 15.86 & 0.83 \\
Soil 19 & 0.03 & 0.072 & 0.10 & 0.586 & 4.19 & 0.015 & 11.00 \\
Soil 20 & 0.05 & 0.019 & 0.06 & 0.573 & 3.73 & 0.021 & 0.79 \\
\hline
\end{tabular}

Table 6: Descriptive statistics for the data collected from soil samples from Covenant farm (L2)

\begin{tabular}{lcccccccc}
\hline \multicolumn{1}{c}{ Statistic } & $\mathrm{Ca}$ & $\mathrm{P}$ & $\mathrm{Mg}$ & $\mathrm{Ti}$ & $\mathrm{Al}$ & $\mathrm{Na}$ & $\mathrm{Fe}$ \\
\hline Arithmetic mean & 0.0643 & 0.0386 & 0.1050 & 0.4588 & 6.0785 & 0.1253 & 7.9729 & 0.3443 \\
Geometric mean & 0.0471 & 0.0347 & 0.0816 & 0.4321 & 5.6028 & 0.0278 & 6.1145 & 0.2344 \\
Harmonic mean & 0.0341 & 0.0312 & 0.0705 & 0.4115 & 5.0698 & 0.0132 & 4.3255 & 0.1280 \\
Quadratic mean & 0.0827 & 0.0423 & 0.1417 & 0.4925 & 6.4641 & 0.2493 & 9.2974 & 0.4312 \\
Median & 0.0500 & 0.0360 & 0.0600 & 0.3725 & 7.0750 & 0.0115 & 8.3000 & 0.2300 \\
SD & 0.0540 & 0.0181 & 0.0988 & 0.1860 & 2.2820 & 0.2237 & 4.9634 & 0.2694 \\
Skewness & 1.5010 & 0.7050 & 2.3410 & 1.9830 & -0.395 & 2.0360 & 0.0120 & 0.7930 \\
\hline
\end{tabular}


Table 7: Correlation matrix for the pair of nutrients in soil samples for Covenant farm (L2)

\begin{tabular}{|c|c|c|c|c|c|c|c|}
\hline $\mathbf{R}$ & $\mathrm{P}$ & $\mathrm{Mg}$ & $\mathrm{Ti}$ & $\mathrm{Al}$ & $\mathrm{Na}$ & $\mathrm{Fe}$ & $\mathrm{K}$ \\
\hline $\mathrm{Ca}$ & 0.333 & 0.879 & 0.623 & -0.126 & 0.363 & 0.177 & 0.734 \\
\hline $\mathrm{P}$ & & 0.625 & 0.558 & 0.410 & -0.200 & 0.776 & 0.319 \\
\hline $\mathrm{Mg}$ & & & 0.838 & 0.135 & 0.263 & 0.390 & 0.767 \\
\hline $\mathrm{Ti}$ & & & & -0.059 & 0.085 & 0.118 & 0.587 \\
\hline $\mathrm{Al}$ & & & & & -0.386 & 0.706 & -0.088 \\
\hline $\mathrm{Na}$ & & & & & & -0.270 & 0.681 \\
\hline $\mathrm{Fe}$ & & & & & & & 0.185 \\
\hline
\end{tabular}

Table 8: Significance table for the correlation matrix for Covenant farm (L2)

\begin{tabular}{lccccccc}
\hline $\mathrm{p}$ value & $\mathrm{P}$ & $\mathrm{Mg}$ & $\mathrm{Ti}$ & $\mathrm{Al}$ & $\mathrm{Na}$ & $\mathrm{Fe}$ & $\mathrm{K}$ \\
\hline $\mathrm{Ca}$ & 0.245 & $\mathbf{0 . 0 0 0}$ & $\mathbf{0 . 0 1 7}$ & 0.668 & 0.203 & 0.544 & $\mathbf{0 . 0 0 3}$ \\
$\mathrm{P}$ & & $\mathbf{0 . 0 1 7}$ & $\mathbf{0 . 0 3 8}$ & 0.145 & 0.493 & $\mathbf{0 . 0 0 1}$ & 0.266 \\
$\mathrm{Mg}$ & & $\mathbf{0 . 0 0 0}$ & 0.646 & 0.364 & 0.167 & $\mathbf{0 . 0 0 1}$ \\
$\mathrm{Ti}$ & & & 0.841 & 0.772 & 0.688 & $\mathbf{0 . 0 2 7}$ \\
$\mathrm{Al}$ & & & & 0.173 & 0.005 & 0.351 \\
$\mathrm{Na}$ & & & & & & \\
$\mathrm{Fe}$ & & & & & & & \\
\hline
\end{tabular}

Table 9: Statistical comparison between Landmark and Covenant farms

\begin{tabular}{lcccc}
\hline Element & $\mathrm{T}$ & $\mathrm{p}$ value & $\mathrm{U}$ score & 0.3936 \\
$\mathrm{Ca}$ & 1.31 & 0.231 & 105 & 0.4128 \\
$\mathrm{P}$ & -0.87 & 0.397 & 79.5 & 0.2748 \\
$\mathrm{Mg}$ & 0.03 & 0.974 & 108.5 & $\mathbf{0 . 0 2 2 2}$ \\
$\mathrm{Ti}$ & 1.7 & 0.107 & 126 & 0.9185 \\
$\mathrm{Al}$ & 0.44 & 0.668 & 94 & 0.4325 \\
$\mathrm{Na}$ & 0.32 & 0.756 & 80 & 0.0945 \\
$\mathrm{Fe}$ & -3.74 & $\mathbf{0 . 0 0 2}$ & 0.2601 \\
$\mathrm{~K}$ & 0.81 & 0.447 & 75 & 0.25 \\
\hline
\end{tabular}

Table 10: Food and agricultural organization standard for macronutrients in soil

\begin{tabular}{|c|c|c|c|c|c|c|}
\hline Ratings & $\begin{array}{r}\text { Nitrogen } \\
(\%)\end{array}$ & $\begin{array}{r}\text { Potassium } \\
(\%)\end{array}$ & $\begin{array}{r}\text { Calcium } \\
(\%)\end{array}$ & $\begin{array}{r}\text { Magnesium } \\
(\%)\end{array}$ & $\begin{array}{r}\text { Sodium } \\
(\%)\end{array}$ & $\begin{array}{r}\text { Phosphorus } \\
(\%)\end{array}$ \\
\hline Low & $<0.08$ & 0.077 & $<0.0005$ & NS & $<0.0789$ & $<0.0007$ \\
\hline Medium & $0.08-0.15$ & $\begin{array}{r}0.077- \\
0.21\end{array}$ & $\begin{array}{r}0.0005- \\
0.004 .6\end{array}$ & NS & $\begin{array}{r}0.0789- \\
0.0157\end{array}$ & $0.0007-0.002$ \\
\hline High & $>0.15$ & $>0.21$ & 0.04 .6 & NS & 0.0157 & $>0.002$ \\
\hline
\end{tabular}

NS - Not supplied Source: Akande (39) and FAO (40) Soil bulletin No 63

Comparing the nutrient accumulation for Locations 1 and 2, the following paired nutrients: $\mathrm{Ca}-\mathrm{Mg}, \mathrm{P}-\mathrm{Mg}, \mathrm{Fe}-\mathrm{Al}, \mathrm{Ca}-\mathrm{K}, \mathrm{Mg}-$ $\mathrm{K}$, and Na-K are positively correlated (Tables 3 and 7). The result further revealed that titanium $(\mathrm{Ti})$ and iron $(\mathrm{Fe})$ content in the soils of the two sites are the same, correlation notwithstanding (Table 9) as previously observed by Lyu et al. (38). Iron and Titanium have been found to have antagonistic and synergistic relationship when $\mathrm{Fe}$ is deficient in soil/plant, Ti help induce genes related to $\mathrm{Fe}$ acquisition thereby improving the overall quality of crop yield (38).

Soil testing of $0.015 \%$ calcium $(\mathrm{Ca})$ is considered normal for nutrient uptake and greater than $0.015 \%$ slows the nutrient uptake by plants (3). Although, all elements analyzed were below the FAO soil quality guidelines (Table 10) except for magnesium 
(mg) limits that were not stated. Cover crops should be rotated with other crops all year round to increase the green manure and supply the necessary depleted nutrients the soil needs. Also, animal dung and manure of organic origin should be added to chemical fertilizers to boost the soil fertility of the study area.

\subsection{Implications of findings on Precision Agriculture}

The results of this study have the implications for improving soil fertility of the farmlands and other farmlands with the same nutrients variability. $\mathrm{L} 1$ soils are richer in calcium $(\mathrm{Ca})$ than the L2 soils. Also, the iron (Fe) concentration in L2 farm exceeds significantly that of $\mathrm{L} 1$ soils. The implication of this is that, plants that are tolerant of calcium-rich soils such as Fenugreek plants should be planted in L1 soil. However, excessive calcium uptake by plants may result in disturbances of ion balance which is detrimental to other nutrients such as magnesium and potassium (41-42). Basically, a small amount of iron (Fe) is required for plant growth but crops such as sweet potatoes and radishes that enjoy iron-rich soils can be planted in L2 soil (43).

Appropriate fertilizers should be added to where it is needed instead of the traditional application of fertilizers to the entire farmland. For nutrient drain effects as a result of erosion on OmuAran farm as observed during the soil samples collection, cover crops such as canola, mustard, oats, wheat and alfalfa should be planted on the elevated portion of the farmland and land tillage be drastically reduced to retain soil fertility.

\section{Conclusion}

The nutrient status of the agricultural soils in the two sites has been investigated. All essential soil elements determined were lower in value than the FAO standard guidelines (Table 10). The study has revealed that potassium $(\mathrm{K})$, aluminum $(\mathrm{Al})$, titanium (Ti) and calcium (Ca) are more in the soils of Omu-Aran (L1) than in the soils samples from Ota (L2). Ota soil is, however, richer in iron (Fe) and magnesium (mg). The findings on the nutrient status have implications for precision agriculture To improve the soil fertility of the two sites investigated, only fertilizers that are enriched in deficient nutrients analyzed should be used. Also, soil management practices and timely irrigation should be adopted as this will help to reduce calcium-related disorders in the soil and allows a steady supply of calcium throughout the crop season. Geostatistical results for the two locations revealed that these paired macronutrients are positively correlated that is, Ca-Mg, $\mathrm{P}$ $\mathrm{Mg}, \mathrm{Fe}-\mathrm{Al}, \mathrm{Ca}-\mathrm{K}, \mathrm{Mg}-\mathrm{K}$, and $\mathrm{Na}-\mathrm{K}$. The correlation at 0.05 level of significance suggests that an increase in the accumulation of one of the paired nutrients leads to an automatic increase in the other. Thallium $(\mathrm{Ti})$ and iron $(\mathrm{Fe})$ have the same concentration in the soils of the two sites correlation notwithstanding. These findings can be used as basic information for the promotion and establishment of sustainable agriculture in the areas investigated. Further investigation is required to determine other trace elements (micro and macronutrients) that were not analyzed in this study. Finally, the world health organization (WHO) and environmental protection agencies should frequently supply the public with soil quality standard guidelines in other to breed healthy crops and improve overall human health.

\section{Acknowledgement}

The authors wish to appreciate Acme Laboratory, Veritas Bureau, Canada for the timely analysis of samples and also Covenant University for sponsoring this publication.

\section{Ethical issue}

Authors are aware of, and comply with, best practice in publication ethics specifically with regard to authorship (avoidance of guest authorship), dual submission, manipulation of figures, competing interests and compliance with policies on research ethics. Authors adhere to publication requirements that submitted work is original and has not been published elsewhere in any language.

\section{Competing interests}

The authors declare that there is no conflict of interest that would prejudice the impartiality of this scientific work.

\section{Authors' contribution}

All authors of this study have a complete contribution for data collection, data analyses and manuscript writing.

\section{References}

1 Lambin, E.F. \& Meyfroidt, P. (2011). Global land use change, economic globalization, and the looming land scarcity. Proceedings of the National Academy of Sciences of the United States of America, 108 (9), 3465-3472.

2 Epstein, E. \& Bloom, A.J. (2005). Mineral Nutrition of Plants: Principles and Perspectives. 2nd Edition, Sinauer Associates, Inc., Sunderland.

3 Havlin, J.L, Tisdale, S.L., Nelson, W.L. \& Beaton, J.D. (2005). Soil fertility and fertilizers: an introduction to nutrient management. $7^{\text {th }}$ Edition, Pearson Educational, Incorporation upper saddle river, New Jersey.

4 Miller, A.J. (2014). Plant Mineral Nutrition. In: e LS. John Wiley \& Sons, Ltd: Chichester.

5 Nielsen, F.H (2003). Encyclopedia of food sciences and nutrition. In B. Caballero (Ed.), Academic Press, Maryland USA.

6 Gupta, U., Wu, K. \& Liang, S. (2008). Micronutrients in Soils, Crops, and livestock. Earth Science Frontiers, 15(5), 110-125.

7 McGrath, J.M., Spargo, J. \& Penn, C.J. (2014). Soil fertility and plant nutrition, In book: Encyclopedia of Agriculture and Food Systems Edition: Second, Publisher: Elsevier, Editors: Neal Van Alfen.

8 Jones, C. \& Olson-Rutz, K. (2016). Soil Nutrient Management for Canola. EB0224. Montana State University Extension, Bozeman, MT.

9 McCauley, A., Jones, C. \& Jacobsen, J. (2011). Plant nutrient functions and deficiency and toxicity symptoms. Nutrient Management Module, 9, 1-16.

10 Jackson, R. B. \& Caldwell, M.M. (1993). The scale of nutrient heterogeneity around individual plants and its quantification with geostatistics. Ecology, 74, 612-614.

11 Stark, J.M. (1994). Causes of soil nutrient heterogeneity at different scales. Pages 255-284 in M.M Caldwell and R. Pearcy (eds.) Exploitation of Environmental Heterogeneity by Plants: Ecophysiological Processes Above and Below Ground. J. Wiley \& Sons, NY.

12 Orians, C.M. \& Zanne, A.E. (2005). Vascular constraints and longdistance transport in Dicots. Editor(s): N. Michele Holbrook, Maciej A. Zwieniecki, In Physiological Ecology, Vascular Transport in Plants, Academic Press, pp. 565-566.

13 Guler, C., Alpasian, M., Kurt, M.A \& Temel, A. (2010). Deciphering factors controlling trace element distribution in the soils of Karaduvar 
industrial-agricultural area (Mersin, SE Turkey). Environmental Earth Sciences, 60(1), 203-218.

14 Tu, C.L, He, T.B., Lu, X.H., Lang, Y.C. \& Li, L.B. (2013). Accumulation of trace elements in paddy topsoil of the Wudang County, Southwest China: parent materials and anthropogenic control. Environmental Earth Sciences, 70 (1), 131-137.

15 Yang, H, Lu, M. \& Cao, J. (2015). Trace elemnts of the soil-plnt systems in subtropical karst and clasolite areas in Guilin, Guangxi, China. Journal of Environmental Earth Science, 73(10), 6259 -6269.

16 Ma, Y., Fu, S., Zhang, X., Zhao, K. \& Chen, H.Y. (2017). Intercropping improves soil nutrient availability, soil enzyme activity and tea quantity and quality. Applied Soil Ecology, 119, 171-178.

17 Tian, L., Zhao, L., Wu, X., Fang, H., Zhao, Y., Yue, G., Liu, G. \& Chen, H. (2017). Vertical patterns and controls of soil nutrients in alpine grassland: Implications for nutrient uptake. Science of the Total Environment, 607-608, 855-864.

18 Yu, C., Pang, X.P., Wang, Q., Jin, S.H, Shu, C.C. \& Guo Z.G, (2017). Soil nutrient changes induced by the presence and intensity of plateau pika (Ochotona curzoniae) disturbances in the Qinghai-Tibet Plateau, China. Ecological Engineering, 106, 1-9.

19 Ward, D., Trinogga, J., Wiegand, K., Toit, J., Okubamichael, D., Reinsch, S. \& Schleicher, J. (2018). Large shrubs increase soil nutrients in a semi-arid savanna. Geoderma, 310, 153-162.

20 Chen, B., Tan, S., Zeng, Q., Wang, A. \& Zheng, H. (2019). Soil nutrient heterogeneity affects the accumulation and transfer of cadmium in Bermuda grass (Cynodon dactylon (L.) pers.). Chemosphere, 221, 342-348.

21 Guo, A., Zhao, Z., Zhang, P., Yang, Q., Li, Y. \& Wang, G. (2019). Linkage between soil nutrient and microbial characteristic in an opencast mine, China. Science of The Total Environment,25, 905913.

22 Jin, Z., Chen, C., Chen, X., Hopkins, I., Zhang, X., Han, Z., Jiang, F. \& Billy, G. (2019). The crucial factors of soil fertility and rapeseed yield - A five-year field trial with biochar addition in upland red soil, China. Science of the Total Environment, 649, 1467-1480.

23 Liu, M., Zhang, Q., Ge, S., Mason R.P., Luo, Y., He, Y., Xie, H., Sa, R. \& Chen, L. (2019), Rapid increase in the lateral transport of trace elements induced by soil erosion in major karst regions of China. Environmental Sciences and Technology, 53(8), 4206-4214.

24 McMahon, D.E, Vergutz, L, Valadares, S.V, Silva, I. \& Jackson, R.B (2019). Soil nutrients stocks are maintained over multiple rotations in Brazilian Eucalyptus plantations. Forest Ecology and Management, 448, 364-375.

25 Tiang, L., Zhao, L., Wu, X., Hu, G., Fang, H., Zhao, Y., Sheng, Y., Chen, J., Wu, J., Li, W., Ping, C., Pang, Q., Liu, Y., Shi, W., Wu, T. \& Zhang, X. (2019). Variations in soil nutrient availability across Tibetan grassland from the 1980s to 2010s. Geoderma, 338, 197-205.

26 Vinograd, A., Zaady, E. \& Kigel, J. (2019). Dynamics of soil nutrients in abandoned sheep corrals in semi-arid Mediterranean planted forests under grazing. Journal of Arid Environment, 164, 38 45.

27 Yao, Y., Shao, M., Fu, X., Wang, X. \& Wei, X. (2019). Effects of shrubs on soil nutrients and enzymatic activities over a $0-100 \mathrm{~cm}$ soil profile in the desert-loess transition zone. Catena, 174, 362-370.

28 USEPA - United States Environmental Protection Agency (2017). The sources and solutions: agriculture. Retrieved from https://www.epa.gov > nutrientpollution >sources and solutionsagriculture.

29 Schmidhalter, F.X, Maidl, H., Demmel, H., Noack, M. \& Rothmund (2008). Precision farming- adaptation of land use management to small scale heterogeneity, Chapter 2.3; Perspectives for Agroecosystem Management, Balancing Environmental and SocioEconomic Demands, 121-199.

30 Finch, S., Samuel, A., \& Lane, G.P. (2014). Lockhart and wiseman's crop husbandry including grassland (9th edition). Woodhead Publishing, http://doi.org/10.1016/C2013-0-23267-0.

31 Aizebeokhai, A.P., Oyeyemi, K.D. \& Kayode, O.T. (2015). Assessment of soil petrophysical parameters using electrical resistivity tomography (ERT) and induced polarization techniques. Research Journal of Applied Sciences, 10 (9), 479-485.

32 Usikalu, M.R., Maleka, P.P., Malik, M., Oyeyemi, K.D. \& Adewoyin, O.O. (2015). Assessment of geogenic natural radionuclide contents of soil samples collected from Ogun State, South western, Nigeria. International Journal of Radiation Research, 13 (4), 355-361.

33 Kayode, O.T., Aizebeokhai, A.P. \& Odukoya, A.M. (2019). Soil characterisation for precision agriculture using remotely sensed imagery in southeastern Nigeria. Journal of Physics Conference Series, 1299, 012070.

34 Bongiovanni, R. \& Lowenberg-Deboer, J. (2004). Precision agriculture and sustainability. Precision Agriculture, 5: 359-387.

35 Obaje, N.G. (2009). Geology and Mineral Resources of Nigeria. Springer, Dordrecht Heidelberg London New York, $221 \mathrm{p}$.

36 Kayode, J.S., Nawawi, M.N.M., Baioumy, H.M., Khalil, A.E. \& Khiruddin, B.A (2015). Delineation of the subsurface geological structures of Omu-Aran area, south-western Nigeria, using aeromagnetic data. AIP Conference Proceedings 1657, 040012.

37 Omotosho, T.V., Omeatan, O., Akinwumi, S.A., Adewusi, O.M., Boyo, A.O. \& Singh, M.J. (2017). Year to year variation of rainfall rate and rainfall regime in Ota, southwest Nigeria for the year 2012 to 2015. Journal of Physics Conference Series, 852 (1), 12013.

38 Lyu, S., Wei, X., Chen, J., Wang C., Wang X. \& Pan, C. (2017). Titanium as a beneficial element for plant production. Frontiers in Plant Science, 8, 597

39 Akande, J.M. \& Ifelola, E.O. (2011). Analysis of Soil, Water and Dust during limestone mining and processing. Mineral Wealth, 157, $15-24$.

40 FAO- Food and agricultural organization (1990). Conducting smallscale nutrition surveys: A field manual. 186p, English, Spanish, French ISBN 202851.

41 Giel, P. \& Bojarczuk, K. (2011). Effects of high concentration salts in the substrate and its $\mathrm{pH}$ on the growth of selected phododendron cultivars. Acta Societatis Botanicorum Poloniae, 80(2), 105-114.

42 Deep, K., Rao, P., Bansl, H. \& Mittal, R. (2014). Matrix effects for calcium and potassium K-X-rays, on fenugreek plants grown in iron rich soils. Applied Radiation and Isotopes, 90, 109-116.

43 Smith, D. (2016). Understanding iron. Retrieved from https://www.agweb.com. Accessed on 25/12/19. 